\title{
Optimal Spacing of Pheromone Traps for Monitoring the Tobacco Moth, Ephestia elutella (Hübner) (Lepidoptera: Phyralidae), in Tobacco Warehouses*
}

\author{
by \\ Toshihiro Imai and Yoshihiro Kasaishi \\ Leaf Tobacco Research Center, Japan Tobacco Inc., Oyama, Tochigi 323-0808, Japan
}

\section{SUMMARY}

Pheromone traps have been widely used for monitoring insect pests in tobacco factories and warehouses. Generally, these traps are placed 10-20 m apart, although a precise scientific rationale for this practice is not available. We examined the effect of trap density on the recovery and localization of tobacco moths released in a $42.3 \times 36.5 \times 4.0 \mathrm{~m}$ tobacco warehouse compartment $\left(1540 \mathrm{~m}^{2}\right)$. In single-trap experiments $\left(0.06\right.$ traps $\left./ 100 \mathrm{~m}^{2}\right)$, $15-51 \%$ (33\% on average) of the released male moths were captured. The capture ratio was not correlated with the distance between the trap and the release point; the highest catch rate was attained when a trap was placed at the most distant position: $47 \mathrm{~m}$ from the release point. Capture data from experiments using groups of 4-23 traps revealed that the highest catch rates were always attained by the trap nearest the release point when more than eight traps $\left(0.5\right.$ traps $\left./ 100 \mathrm{~m}^{2}\right)$ were set. These results indicate that the number of traps required for monitoring purposes should be changed - one trap is sufficient for detecting the presence or absence of infestation in a $1540 \mathrm{~m}^{2}$ warehouse compartment $\left(0.06\right.$ traps $\left./ 100 \mathrm{~m}^{2}\right)$; more than eight traps $\left(0.5\right.$ traps $\left./ 100 \mathrm{~m}^{2}\right)$ should be set for localization, allowing the location of the infestation to be inferred from the trap with the highest catch rate. [Beitr. Tabakforsch. Int. 24 (2011) 289-292]

\section{ZUSAMMENFASSUNG}

In Tabakfabriken und -lagern werden häufig Pheromonfallen zur Kontrolle von Insektenbefall eingesetzt. Diese Fallen werden im Allgemeinen in einem Abstand von 10 bis $20 \mathrm{~m}$ aufgestellt, allerdings gibt es dafür keine belastbare wissenschaftliche Grundlage. Wir haben die Auswirkung der Fallendichte auf den Nachweis und die Lokalisierung der in einem 42,3 × 36,5 × 4,0 m großen Tabaklager $\left(1.540 \mathrm{~m}^{2}\right)$ freigesetzten Tabakmotten untersucht. In einem Experiment mit einer Einzelfalle $(0,06$ Fallen $/ 100 \mathrm{~m}^{2}$ ) wurden $15-51 \%$ (durchschnittlich 33\%) der freigesetzten männlichen Motten eingefangen. Die Einfangquote korrelierte nicht mit der Entfernung zwischen Falle und Punkt der Freisetzung; die höchste Einfangquote wurde bei der am weitesten entfernt aufgestellten Falle erreicht: 47 m vom Punkt der Freisetzung. Die Einfangdaten aus Experimenten mit Gruppen von 4 bis 23 Fallen zeigen, dass die Einfangquoten bei der dem Punkt der Freisetzung nächstgelegenen Falle am höchsten waren, wenn mehr als 8 Fallen (0,5 Fallen/100 $\left.\mathrm{m}^{2}\right)$ aufgestellt wurden. Diese Ergebnisse weisen darauf hin, dass die Anzahl der zur Überwachung erforderlichen Fallen geändert werden sollte - eine Falle reicht aus, um einen Befall in einem $1.540 \mathrm{~m}^{2}$ großen Lager $(0,06$ Fallen $/ 100 \mathrm{~m}^{2}$ ) festzustellen oder auszuschließen; mehr als 8 Fallen $\left(0,5\right.$ Fallen $\left./ 100 \mathrm{~m}^{2}\right)$ sollten zur Lokalisierung aufgestellt werden, denn anhand der Falle mit der höchsten Einfangquote kann auf die Lage des Befalls geschlossen werden. [Beitr. Tabakforsch. Int. 24 (2011) 289-292]

\section{RESUME}

Les pièges à phéromones ont été largement utilisés pour surveiller la présence d'insectes dans les usines et entrepôts de tabac. En général, ces pièges sont espacés de 10 à $20 \mathrm{~m}$ les uns des autres, bien que cette pratique ne soit fondée sur aucun motif scientifique précis. Nous avons étudié l'efficacité de la densité de placement des pièges sur le plan de la recapture et de la localisation des teignes du 
tabac lâchées dans un compartiment d'entrepôt de tabac de $42,3 \times 36,5 \times 4,0 \mathrm{~m}\left(1540 \mathrm{~m}^{2}\right)$. Dans le cadre d'essais menés avec un unique piège $\left(0,06\right.$ piège $\left./ 100 \mathrm{~m}^{2}\right), 15$ à $51 \%$ (soit 33\% en moyenne) des teignes mâles lâchées ont été recapturées. Le taux de capture ne dépendait pas de la distance entre les pièges et le point de relâche; le taux de capture le plus élevé a été atteint avec un piège positionné à distance maximale du point de relâche, soit à $47 \mathrm{~m}$ de celui-ci. Des données de capture obtenues au cours d'essais utilisant des groupes de 4 à 23 pièges ont montré que les taux de capture les plus élevés étaient toujours atteints par le piège placé le plus près du point de relâche lorsqu'on utilisait plus de huit pièges $\left(0,5\right.$ piège $\left./ 100 \mathrm{~m}^{2}\right)$ pour l'essai. Ces résultats indiquent qu'il faudrait modifier le nombre de pièges nécessaires pour les objectifs de surveillance: un seul piège suffit pour établir la présence ou l'absence d'une infestation dans un compartiment d'entrepôt de $1540 \mathrm{~m}^{2}\left(0,06\right.$ piège/100 $\left.\mathrm{m}^{2}\right)$; plus de huit pièges $\left(0,5\right.$ piège $\left./ 100 \mathrm{~m}^{2}\right)$ doivent être utilisés pour un objectif de localisation, l'emplacement du foyer d'infestation pouvant être déduit à partir de l'emplacement du piège avec le taux de capture le plus élevé. [Beitr. Tabakforsch. Int. 24 (2011) 289-292]

\section{INTRODUCTION}

The semiochemicals of many of the major stored-product pests have been elucidated in previous studies, and trapping systems based on these chemicals are well established $(1,2)$. Pheromone traps for the major pests in the tobacco industry - the tobacco moth (Ephestia elutella) and the cigarette beetle (Lasioderma serricorne) - have been used extensively in manufacturing, storage and transportation facilities in IPM programs targeting these pests (3). In a previous study, we determined several factors that affect the performance of pheromone traps for the tobacco moth and proposed a preferred trap placement design: on the surfaces of walls, pillars and stored commodities; at a height of 1 to $2 \mathrm{~m}$ (4). However, the trap density required was not determined. The recommended spacing of traps varies between pheromone trap manufacturers (note that some manufacturers use units of meters; other use feet): $5-10 \mathrm{~m}$ apart $\left(1-4 \operatorname{traps} / 100 \mathrm{~m}^{2}\right)$, 25-50 ft apart $\left(0.43-1.72 \operatorname{traps} / 100 \mathrm{~m}^{2}\right), 16-20 \mathrm{~m}$ apart $\left(0.25-0.39\right.$ traps $\left./ 100 \mathrm{~m}^{2}\right)$ and $15-20 \mathrm{~m}$ apart $(0.25-0.44$ traps $\left./ 100 \mathrm{~m}^{2}\right)(5,6,7,8)$. The labor cost for trap inspection and the material cost of traps are proportional to the number of traps installed. Therefore, trap density is an important factor in cost management of pest-control activities. The present study evaluated the influence of trap density on trapping efficiency and determined the optimal spacing for monitoring the tobacco moth in warehouses.

\section{MATERIALS AND METHODS}

\section{Release-capture tests in a tobacco warehouse}

The tobacco moth culture used in this study was the same as that described in our previous paper (4). Release-capture tests were performed in a $42.2 \times 36.5 \times 4.0 \mathrm{~m}$ tobacco warehouse compartment $\left(1540 \mathrm{~m}^{2}\right)$ in which tobacco dust in flexible container bags and unused pallets were stored (Figure 1). The absence of tobacco moths in the room was confirmed using pheromone trap monitoring before testing. Commercial pheromone traps (Fuji Trap Gachon; Fuji Flavor Co., Ltd., Tokyo) were mounted on pillars (vertical beams) and walls at a height of $2 \mathrm{~m}$. Temperatures, which were uncontrolled, varied from 25.1 to $31.9^{\circ} \mathrm{C}$ during the tests.

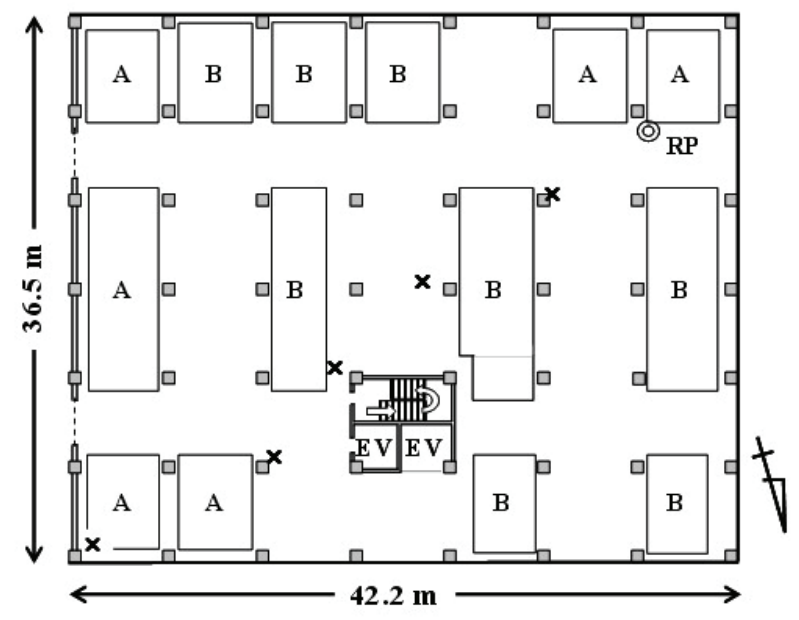

Figure 1. Layout of the test warehouse compartment $(\mathbf{4 2 . 2} \times \mathbf{3 6 . 5} \times \mathbf{4 . 0} \mathrm{m})$. Filled squares represent pillars (vertical beams) arranged in a grid pattern of $6 \mathrm{~m}$ squares $(8 \times 7=56$ pillars). A stairwell and elevators ("EV") are situated at the center to the north. Piles of unused pallets (2-3 $\mathrm{m}$ high) and of flexible container bags of tobacco dust (1.5-1.8 $\mathrm{m}$ high) were stored in areas "A" and "B", respectively. Marks " $x$ " represent trap positions in Experiment 1. A trap was placed at one of these five positions, and 100 males were released from the location indicated by the double circle (release point; "RP").

Experiment 1: Evaluation of the active range of a single trap

A trap was placed on one of five pillars aligned diagonally from the release point, at distances of $8.5,17,25.5,34$, and $46.9 \mathrm{~m}$ (the locations are marked with " $\times$ " in Figure 1). One hundred male moths were released from the floor near the southwest corner ("RP" in Figure 1), and trap catches were counted 3-4 days after the release.

\section{Experiment 2: Evaluation of trapping efficiency in relation to trap density}

Groups of 4, 8, 15, 19 and 23 traps were placed around the room (Figure 2: A-F). Then, 200 male moths were released from the floor ("RP" in Figure 2), and trap catches were counted seven days after release. Experiments using a group of four traps were repeated and those using groups of $8,15,19$ and 23 traps were performed once.

\section{Spatial analyses}

The spatial distribution of catches was examined by contour analysis using the Surfer 8.0 computer program (Golden Software Inc., Colorado) with kriging for interpolation using a linear variogram model and a nugget effect of zero $(9,10)$. 


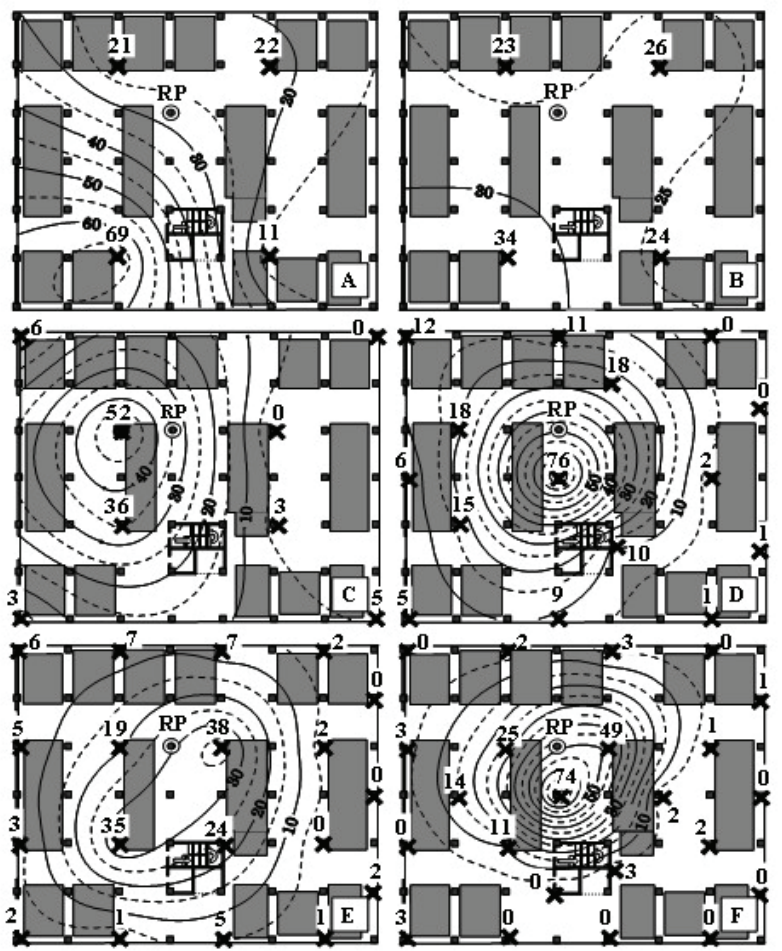

Figure 2. Contour maps of tobacco moth distribution estimated from trap catches using 4 (A and B, replication), 8 (C), $15(D), 19(E)$ and 23 traps (F) (Experiment 2). Numbers represent catches by respective traps. "RP" represents the release point.

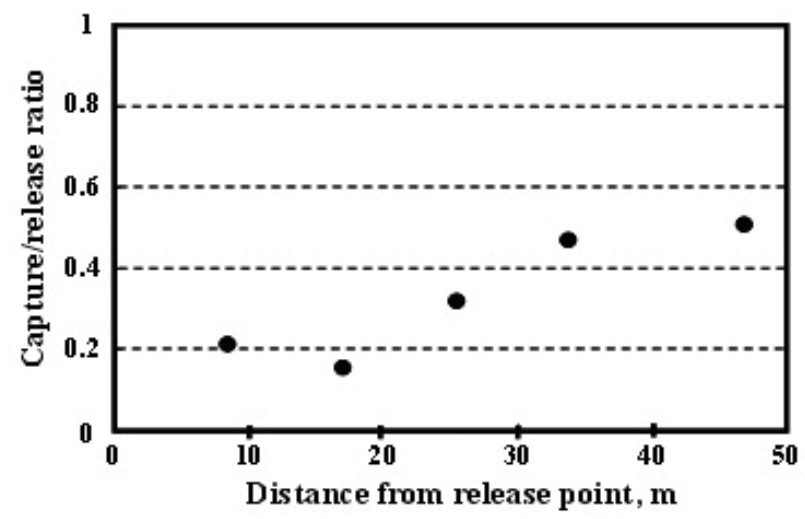

Figure 3. Capture/release ratio in relation to the distance between trap and release point in single-trap experiments (Experiment 1).

\section{RESULTS AND DISCUSSION}

\section{Active range of a single trap}

In the single-trap experiments (Experiment 1), 15-51\% (33\% on average) of the released moths were captured. Figure 3 shows the capture/release ratio for the distance between the trap and the release point. The capture/release ratio was expected to decrease with increasing distance. However, we did not find such a correlation: the highest catch rate was attained when the trap was placed at the most distant position, $46.9 \mathrm{~m}$ from the release point. The sampling range of a trap includes both the distance over which insects are attracted and the distance that they might have traveled before attraction (11). The range of attraction has been demonstrated to be $60-1,600 \mathrm{~m}$ for some field Lepidopteran species (11) but is thought to be smaller in indoor storage environments: For the Indian meal moth, Plodia interpunctella, whose sex-pheromone components are identical to those of the tobacco moth, the active space of a lower-dose pheromone lure was demonstrated to be less than $4 \mathrm{~m}$ (12). The active range of the pheromone lure used in our experiments has not been confirmed, but the results indicate that the practical sampling range, including the flight range of the tobacco moth, is greater than $50 \mathrm{~m}$; thus, a single trap could serve the entire room $\left(1540 \mathrm{~m}^{2}\right)$ sufficiently.

\section{Trap density}

Figure 4 shows the capture/release ratio in relation to trap density. The capture/release ratio $(y)$ increased with increasing density $(x)$, fitted with a logistic regression curve:

$y=1 /\left(1+1.985 e^{-2.306 x}\right), R^{2}=0.870$.

The results of Experiments 1 and 2 suggest that one trap for a $1540-\mathrm{m}^{2}$ room $\left(0.06\right.$ traps $\left./ 100 \mathrm{~m}^{2}\right)$ is sufficient for detecting the presence or absence of infestation and monitoring the population trend. Jones (13) has cautioned that data collected from a single trap are less reliable than the average of data for more than one trap at a given location. More than one trap should be placed (irrespective of the floor area) when positional variations are suspected because of sampling-space heterogeneity.

When more than eight traps were set, the highest catch rates were attained with the trap nearest the release point, and catch rates decreased with increased distance (Figure 2: C-F). By contrast, four-trap experiments provided no positional information related to the release point (Figure 2: A, B). These results suggest that the location of an infested area can be expected to be found near the site of the peak catch when a $1540-\mathrm{m}^{2}$ warehouse is monitored using more than eight traps $\left(0.5\right.$ traps $\left./ 100 \mathrm{~m}^{2}\right)$.

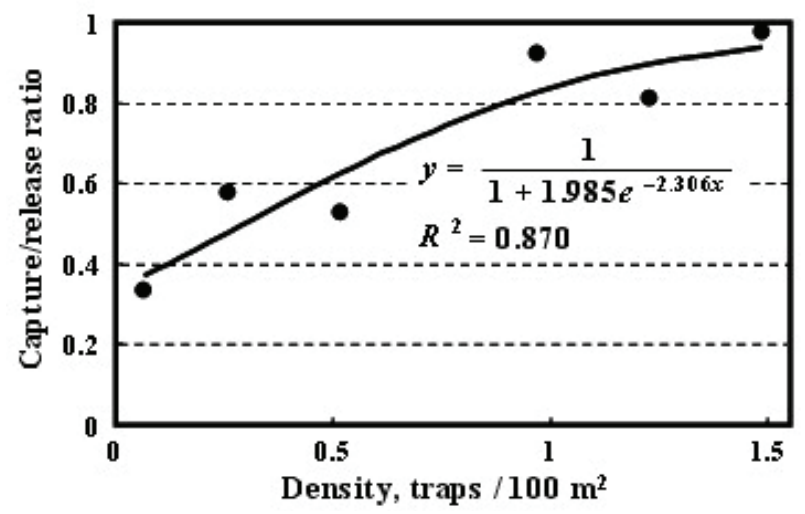

Figure 4. Capture/release ratio in relation to trap density (Experiments 1 and 2). 
Contour analysis offered no additional information under this experimental design, by which moths were released from a single point, but strongly supported the suggestion that an infested area is near the peak catch rate. More than 10 data points are required for precise contour analysis (14). NANSEN et al. (15) recommended semivariogram analysis before interpolation for purposes of interpreting the spatial structure affecting the accuracy of contour mapping. For semivariogram analysis, the required data points are dependent on the shape of the sampling space and the pattern of trap placement (15). Theoretically, $6 \times 6=36$ traps are required for a square room using grid placement. In Japan, storage spaces in tobacco warehouses are generally divided into $1,000-$ to $2,000-\mathrm{m}^{2} \mathrm{com}-$ partments. Consequently, for accurate contour analysis, traps should be placed at densities of more than 1.8-3.6 traps $/ 100 \mathrm{~m}^{2}$. Monitoring using traps set at these higher densities is possible for research purposes in a given restricted space, but for typical pest-control activities in larger storage facilities, the labor involved might be impractical. Therefore, simple mapping of insect counts, such as with scale-sized dots, represents a practical and robust visualization method in standard commercial situations because contour mapping is not reliable when data sets are deficient or when the spatial structure of data sets is random (15).

Detection of infestation, threshold detection, and density estimation have been described as the primary uses of monitoring traps $(13,16)$. In locations where storedproduct insects are unacceptable, such as in food-storage environments, monitoring traps are used for early detection and localization of infestation (1). The results of this study validate the use of tobacco moth pheromone traps for both detection and localization, with different densities of trap placement: 0.06 traps $/ 100 \mathrm{~m}^{2}$ for early detection and 0.5 traps $/ 100 \mathrm{~m}^{2}$ for localization of an infested area.

\section{ACKNOWLEDGMENT}

The authors would like to thank Toshikazu Harima of JT Logistics Co. Ltd. for assistance in experiments at the tobacco warehouse.

\section{REFERENCES}

1. Burkholder, W.E.: Practical Use of Pheromones and Other Attractants for Stored-Product Insects; in: Behavior-Modifying Chemicals for Insect Management, edited by R.L. Ridgway, R.M. Silverstein, and M.N. Inscoe, Marcel Dekker, Inc., NY, USA 1990, pp. 497-516.

2. Phillips, T.W.: Semiochemicals of stored-product insects: Research and applications; J. Stored Prod. Res. 33 (1997) 17-30.

3. Ryan, L. (ed.): Monitoring; in: Post-harvest tobacco infestation control, Kluwer Academic Publishers, Dordrecht, The Netherlands 1999, pp. 25-36.

4. Imai, T., Y. Kasaishi, and T. Fukushima: Influence of Trap Position with Respect to Height and Placement Surface on Capture of the Tobacco Moth, Ephestia elutella (Hübner) (Lepidoptera: Pyralidae), in Pheromone Traps; Beitr. Tabakforsch. Int. 24 (2010) 29-32.

5. Anonymous: Product information; Fuji Flavor Co. Ltd., Tokyo (accessed August 2011) http://www.fjf. co.jp/en/ecomon/product/gachon/index.html

6. Anonymous: How to use pheromones; Insects Limited, Inc. (accessed August 2011) http://www.insects limited.com/pheromones-use.php

7. Anonymous: Stored product moth trapping; AgriSense-BCS Limited, South Wales (accessed August 2011) http://www.agrisense.co.uk/resources/ Attachments/Brochure\%20-\%20Moth\%20-\%20EN.pdf

8. Anonymous: Contrap; Borgwaldt Flavor $\mathrm{GmbH}$, Hamburg (accessed August 2011) http://www. borgwaldt.de/cms/fileadmin/downloads/Borgwaldt_ Flavor/CONTRAP2008.pdf

9. Arbogast, R.T., D.K. Weaver, P.E. Kendra, and R.J. Brenner: Implications of spatial distribution of insect populations in storage ecosystems; Environ. Entomol. 27 (1998) 202-216.

10. Brenner, R.J., D.A. Focks, R.T. Arbogast, D.K. Weaver, and D. Shuman: Practical use of spatial analysis in precision targeting for integrated pest management; Am. Entomol. 44 (1998) 79-101.

11. Wall, C. and J.N. Perry: Range of action of moth sexattractant sources; Entomol. Exp. Appl. 44 (1987) 5-14.

12. Mankin, R.W., R.T. Arbogast, P.E. Kendra, and D.K. Weaver: Active spaces of pheromone traps for Plodia interpunctella (Lepidoptera: Pyralidae) in enclosed environments; Environ. Entomol. 28 (1999) 557-565.

13. Jones, O.T.: Pest monitoring; in: Insect pheromones and their use in pest management, P. Howse, J. Stevens, and O.T. Jones, Chapman \& Hall, London, UK, 1998, pp. 263-279.

14. Anonymous: Surfer 8 User's Guide; Golden Software, Inc., CO, USA, 2002.

15. Nansen, C., J.F. Campbell, T.W. Phillips, and M.A. Mullen: The Impact of Spatial Structure on the Accuracy of Contour Maps of Small Data Sets; J. Econ. Entomol. 96 (2003) 1617-1625.

16. Wall, C.: Principles of Monitoring; in: BehaviorModifying Chemicals for Insect Management, edited by R.L. Ridgway, R.M. Silverstein and M.N. Inscoe, Marcel Dekker, Inc., NY, USA 1990, pp. 9-23.

\section{Corresponding author:}

Toshihiro Imai

Leaf Tobacco Research Center

Japan Tobacco Inc.

Idei 1900, Oyama,

Tochigi 323-0808, Japan

E-mail:toshihiro.imai@jt.com 